\section{Impacts of Huanglongbing Symptom Severity on Fruit Detachment Force and Mechanical Properties of Sweet Oranges (Citrus sinensis)}

\author{
Hong Chen \\ College of Engineering, Huazhong Agricultural University, Wuhan, Hubei \\ 430070, China; and U.S. Horticultural Research Laboratory, USDA, ARS, \\ 2001 South Rock Road, Fort Pierce, FL 34945 \\ Greg McCollum, Elizabeth Baldwin, and Jinhe Bai ${ }^{1}$ \\ U.S. Horticultural Research Laboratory, USDA, ARS, 2001 South Rock \\ Road, Fort Pierce, FL 34945
}

Additional index words. abscission, fruit drop, peel toughness, fruit firmness, puncture damage

\begin{abstract}
This study evaluated the effects of huanglongbing (HLB) symptom severity on fruit detachment force (FDF) and fruit mechanical properties in sweet oranges (Citrus sinensis) as indicators of potential HLB-influenced preharvest fruit drop and postharvest damage and breakdown. FDF for fruit from HLB-asymptomatic trees (AS) was substantially greater than for fruits from HLB-symptomatic trees or branches. Fruit hardness, resilience, springiness, and cohesiveness values, measured by texture profile analysis (TPA), represent various aspects of fruit firmness and recovery capacity once compressed, and were lower in HLB-symptomatic fruits in comparison with AS fruits. On the other hand, puncture force, toughness, and deformation values, measured by a puncture test and representing peel toughness, were higher in HLB-symptomatic fruits than in the AS fruits. The results indicate that fruits from severely HLB-symptomatic sweet orange trees are more likely to have problems with preharvest fruit drop, and postharvest pressure damage and breakdown, but may have less puncture damage in harvesting, transportation, packing, and juice processing.
\end{abstract}

Citrus HLB or greening is a devastating citrus disease associated with Candidatus Liberibacter asiaticus (CLas). HLB has been reported in 40 countries in Asia, Africa, Australia, South America, and North America and was originally discovered in southern China in 1919 (Bové, 2006). After being infected with CLas, citrus trees develop HLB symptoms including decline with typical symptoms such as reduced plant height, yellow shoots, blotchy mottled leaves, canopy thinning, premature abscission of fruits, and some out-of-season flushing and flowering (Bové, 2006; da Graça, 1991). HLB severely affected fruit are small, lopsided,

Received for publication 5 Nov. 2015. Accepted for publication 19 Feb. 2016.

We thank the China Scholarship Council (201206765008) and Fundamental Research Funds for the Central Universities of China (2013PY127) for their financial support for this research.

Mention of a trademark or proprietary product is for identification only and does not imply a guarantee or warranty of the product by the U.S. Department of Agriculture. The U.S. Department of Agriculture prohibits discrimination in all its programs and activities on the basis of race, color, national origin, gender, religion, age, disability, political beliefs, sexual orientation, and marital or family status.

${ }^{1}$ Corresponding author. E-mail: jinhe.bai@ars. usda.gov.

peel and fruit physcal and biomechanica properties, which may contribute to mechanical injury of fruit during harvest, and postharvest handling and processing, and may also influence juice extraction and resulting juice quality. Tissue morphology (cell size, cell arrangement, and cell wall structure etc.) and material composition of fruits have an effect on their mechanical properties. Puncture, compression, cutting, tensile, shear, and TPA tests are usually used to estimate the maturity or resistance of fruit to force (Singh and Reddy, 2006). It has been reported that the maximum force in a puncture test represents the resistance of the fruit peel, and the force-deformation ratio in a whole fruit compression test represents whole fruit resistance (Ortiz and Torregrosa, 2014).

McDonald and Shaw (1987) and Juste et al. (1988) found that puncture resistance of citrus peel decreased with fruit age. The force required to puncture or burst a fruit is directly related to the contact area. This is a function of two variables: the punch diameter used and the radius of curvature of the fruit. The fruit can withstand higher contact forces when subjected to larger punch diameter (Flood et al., 2006). 'Dancy' tangerines and 'Navel' and 'Temple' oranges showed lowest resistances to rupture (7.8, 20.6, and $92.1 \mathrm{~N}$, respectively) and puncture force $(0.5,1.1$, and $6.5 \mathrm{~N}$, respectively); 'Duncan' grapefruit and 'Valencia' orange had medium resistance with 283.2 and 199.9 $\mathrm{N}$ in rupture force, respectively, and 8.5 and $11.8 \mathrm{~N}$ in puncture force, respectively; however, lemon and lime showed the highest resistance to rupture with 356.7 and $371.4 \mathrm{~N}$, respectively, and to puncture with 30.4 and $39.2 \mathrm{~N}$, respectively (Ahmed et al., 1973). Miller (1986) also showed significant differences in compression force and puncture parameters among varieties of citrus. No significant differences for harvest time (after reaching harvest maturity), or abscission chemical application was detected for burst, puncture, and peel tensile strength properties in three orange varieties (Churchill et al., 1980). Singh and Reddy (2006) studied postharvest physico-mechanical property changes of 'Nagpur' mandarins by performing peel tensile tests, peel cutting, fruit compression, puncture resistance, and fruit cutting tests under ambient and refrigerated storage conditions, and found that the peel tensile strength, modulus of elasticity, and cutting force decreased with storage period in both ambient and refrigerated conditions. In contrast to these studies, little is known about how a disease, such as HLB, affects peel and fruit mechanical properties in citrus, thus this study explores these effects in two major Florida juice orange varieties, 'Hamlin' and 'Valencia'. The aim of this study was to assess the effect of HLB symptom severity on FDF and fruit mechanical properties in sweet oranges as indicators of potential HLBinfluenced preharvest fruit drop and postharvest fruit damage and breakdown.

\section{Materials and Methods}

Plant materials. Fifteen-year-old 'Hamlin' and 'Valencia' orange trees [C. sinensis (L.) Osbeck] on 'Swingle' citrumelo [Citrus paradisi Macf. $\times$ Poncirus trifoliata (L.) Raf.] rootstock, in a commercial grove 
located in Vero Beach, FL, were selected for this experiment. The trees received common cultural practices and the grower's standard pest and disease management, which means that enhanced nutritional and pesticide/fungicide spray programs were applied to maintain vigor and productivity of the trees under the severe HLB pressure (Baldwin et al., 2012). For each cultivar, experimental trees were located in a two-acre block, the border trees/rows were excluded from sampling, and trees with average canopy sizes were selected. The experimental trees were tested by real-time polymerase chain reaction in late 2013 by using the method of Li et al. (2006), and all were $C$ Las positive, despite that some trees were not yet showing HLB symptoms.

The study was conducted using a randomized complete block design with five replicates. For 'Hamlin', three conditions/types of fruit samples were collected. The first type was from severely symptomatic HLB trees (HLB) with twig dieback, short shoots, blotchy mottle, curled leaves, and small, misshapen fruits. The second type was from HLB-symptomatic branches (HLB-B) on trees for which at least $50 \%$ of the canopy was HLB asymptomatic. The third type was fruits from HLB-asymptomatic trees (showing no visible HLB symptoms, AS). 'Hamlin' fruits were sampled on 18 Nov. and 2 and 16 Dec. 2013 and 6 Jan. 2014. Twelve fruits, of average size, shape, and color, per replicate/ tree were sampled on each date. Fruit with attached stems $(\approx 50 \mathrm{~mm})$ were clipped in the early morning and transferred to the laboratory within $2 \mathrm{~h}$.

For 'Valencia', only two types of fruit were collected, AS and HLB, because it was not possible to find trees that qualified as HLB-B trees. Samples were taken on 19 Jan., 3 and 19 Feb., and 3 Mar. 2014 in the same manner as for 'Hamlin'.

Fruit detachment force. The FDF was measured using a digital pull force gauge (Force Five; Wagner Instruments, Greenwich, CT). Fruit stems, $50 \mathrm{~mm}$ in length, were secured by a clamp, which was connected to the force gauge (Burns et al., 2003; Pozo et al., 2004). Fruit were then twisted and pulled to emulate hand harvesting. Pulling was performed vertically along the longitudinal axis direction of the fruit and then bent to one side until the stem separated from the fruit. The force was expressed in Newton. At each harvest, 60 fruits were used per HLB condition (HLB, HLB-B, and AS).

Visual classification of fruit color and abscission zone types. Directly after measurement of FDF, the pattern and color of the detachment zone were evaluated from both fruit and stem (peduncle) ends and designated as abscission zone $\mathrm{C}$ (AZ C) detachment and non-AZ $\mathrm{C}$ detachment. AZ $\mathrm{C}$ detachment indicates fruit detached from abscission $\mathrm{AZ} \mathrm{C}$, with a round and smooth detachment scar with dark brown color on the fruit end and no attached calyx. On the stem end, the columella vascular bundles were dark brown with irregular indentations (Fig. $1 \mathrm{~A}$ and B). All other types of detachment,
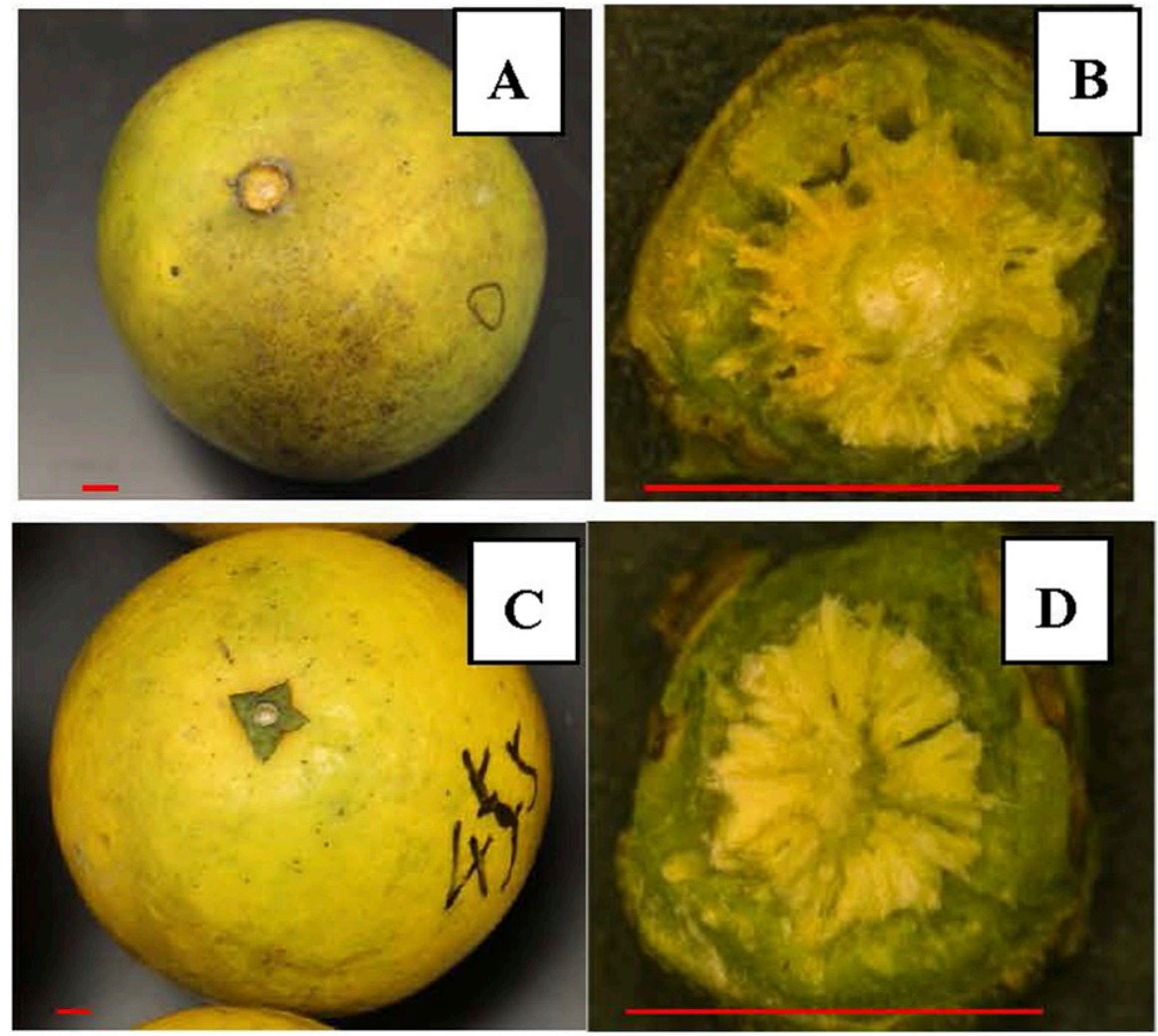

Fig. 1. Different types of detachment of 'Hamlin' orange fruits from stems. (A) Detached at the abscission zone C (AZ C) in HLB fruits and (B) the microscope image of stem detachment surface. (C) Detached through physical breakage of the vascular bundle due to external force in AS fruits and (D) the microscope image of stem detachment surface. AS = fruit harvested from HLB-asymptomatic trees, $\mathrm{HLB}=$ fruit harvested from HLB-symptomatic trees. Scale bars, $5 \mathrm{~mm}$.

usually caused by physical breakage of the vascular bundles due to the pulling force, left the calyx remaining on the fruit side. Meanwhile, the broken stem end often showed a fresh green (outer layer of phloem tissue) and white (inner xylem tissue) surface with clear boundaries separating these two tissues (Fig. 1C and D). Similar differences were seen in 'Valencia', but data were only collected for 'Hamlin'.

Texture profile analysis. The TPA test was carried out using a texture analyzer (TA-XT2i; Stable Micro Systems, UK) calibrated with a 5-kg load cell and equipped with a 60-mm-diameter flat plate. The methods were adapted from Mavroudis et al. (2004) with some modification. The equatorial area of fruit was compressed twice with a loading displacement of $12 \mathrm{~mm}$. The test conditions were as follows: pretest, test, and posttest speeds were all $1 \mathrm{~mm} \cdot \mathrm{s}^{-1}$, trigger value was $0.25 \mathrm{~N}$, and the time of stay was 2 $\mathrm{s}$. The test mode was longitudinal compression. Twenty fruits were used per fruit type (HLB, HLB-B, and AS).

Fruit puncture. Fruit puncture resistance was measured using the same equipment as above with a cylindrical probe $(3 \mathrm{~mm}$ diameter). The methods were adapted from Flood et al. (2006) with some modification. Stroke speed was $2 \mathrm{~mm} \cdot \mathrm{s}^{-1}$, and the probe travel distance after touching the fruit was $15 \mathrm{~mm}$. Posttest speed was 6 $\mathrm{mm} \cdot \mathrm{s}^{-1}$. Each fruit sample was punctured at three equidistant locations along the equatorial region of the fruit. Twenty fruits were used per fruit type.

Statistical analysis. The PASW Statistics 17 software (SPSS, Inc., Chicago, IL) was used for statistical analysis based on each fruit as a unit and differences at $P \leq 0.05$ were considered significant. For the normal distribution data obtained from TPA and puncture tests, one-way analysis of variance was used to analyze the differences among the fruit types, and mean separation was determined by Duncan's multiple range test. Where FDF data were skewed either because samples contained " 0 " value FDFs (fruit separated from the stem without pulling) or there were FDFs that exceeded the maximum scale of the instrument $(60 \mathrm{~N})$, Wilcoxon's test was used. For paired data obtained from 'Valencia' (HLB vs. AS), $t$ test for two independent samples was used to determine significance.

\section{Results and Discussion}

Fruit detachment force. In 'Hamlin' fruit, $24 \%$ of HLB-symptomatic fruits detached from peduncles at the $\mathrm{AZ} \mathrm{C}$, leaving a round and smooth detachment scar with dark brown columella vascular bundles on the calyx end (Fig. 1A and B; Table 1). The AZ C detachment on 18 Nov. 2013 occurred in $26.7 \%$ and $20.0 \%$ of the HLB and HLB-B samples, respectively, increased to $33.3 \%$ and $60.0 \%$, 
respectively, on 2 Dec. 2013 and then consistently decreased until the end of the season (Table 1). On the other hand, all AS fruits exhibited non-AZ $\mathrm{C}$ detachments (0 AZ C detachment, Table 1). This type of detachment usually was caused by physical breakage of the vascular bundle and surrounding tissues with uneven and light colored detachment scars on both fruit and peduncle sides, with the calyx usually remaining on the fruit (Fig. 1C and D). A similar observation was recorded by Liao and Burns (2012). Etxeberria et al. (2009) reported that starch accumulated conspicuously in xylem parenchyma cells of the HLB-affected stems, the cambial zone between the phloem and the xylem was damaged as the result of phloem collapse, the phloem and the xylem were separated and the tissue in the cross section was loose with a tan color. In contrast, the cells in the tissue of the phloem and xylem in the cross section of an AS stems was dense with a complete cambial zone with a fresh white or light yellow color. Zhao et al. (2015) reported that Diplodia fungal hyphae (Lasiodiplodia theobromae or Diplodia natalensis) in HLB fruits may be associated with AZ C appearance.

Values for FDF for each fruit type (HLB, HLB-B, or AS) and at each sampling time showed a normal, or nearly normal distribution in 'Hamlin' fruits (Fig. 2A-D). Generally, average FDF of the fruits from AS trees was higher than that of the fruits from HLB and HLB-B $(P<0.05)$. Average FDF values were higher in 6 Jan. 2014 AS and HLB-B samples in comparison with other sampling dates (Fig. 2A-D), indicating that advanced maturity correlated with increased FDF for those fruits.

Similar patterns in FDF were observed with 'Valencia' fruits. Average FDF for fruit from AS trees was significantly higher than that of the fruits from HLB, except on 19 Feb. 2014 (Fig. 2E-H). The fruits with progressed maturity generally had higher FDF values than the less mature fruits for both AS and HLB samples (Fig. 2E-H).

In an earlier study, abscisic acid (ABA) in the flavedo of the HLB-affected fruits was found to be significantly higher than in the flavedo of AS fruits, which could accelerate fruit loosening and premature abscission (Rosales and Burns, 2011). As a result, the formation of the abscission zone between the stem and pedicel accelerated detachment at the fruit AZ C (Racskó et al., 2006). Zhao et al. (2015) observed that infection by $D$. natalensis, a fugal pathogen that causes postharvest stem-end rot in citrus, may contribute to preharvest fruit drop. A possible mechanism is that HLB weakens the tree and allows for preharvest growth of Diplodia in AZ C, which in turn, results in increased ethylene production and thereby formation of the abscission zone (Zhao et al., 2015). Another possible explanation is that HLB injury to the roots resulted in tree/fruit water stress, increased ABA in the fruit/stems promotion of ethylene production, concurrent AZ formation, and Diplodia development. Nevertheless,

Table 1. Percentage of fruits detached at the abscission zone $\mathrm{C}$ in 'Hamlin' orange fruit at different sampling times.

\begin{tabular}{lcccr}
\hline & 18 Nov. 2013 & 2 Dec. 2013 & 16 Dec. 2013 & 6 Jan. 2014 \\
\hline AS $^{\mathrm{z}}$ & $0 \mathrm{~b}^{\mathrm{y}}$ & $0 \mathrm{c}$ & $0 \mathrm{c}$ & $0 \mathrm{c}$ \\
HLB & $26.7 \mathrm{a}$ & $33.3 \mathrm{~b}$ & $13.3 \mathrm{~b}$ & $6.7 \mathrm{~b}$ \\
HLB-B & $20.0 \mathrm{a}$ & $60.0 \mathrm{a}$ & $21.7 \mathrm{a}$ & $13.0 \mathrm{a}$ \\
\hline
\end{tabular}

${ }^{2} \mathrm{AS}$ = fruit from HLB-asymptomatic trees; HLB = fruit from HLB-symptomatic trees; and HLB-B = fruit specifically from HLB-symptomatic branches in trees with $>50 \%$ asymptomatic canopy.

${ }^{y}$ Means within a column in same day followed by the same letter were not significantly different at $P \leq 0.05$.

Hamlin

Valencia
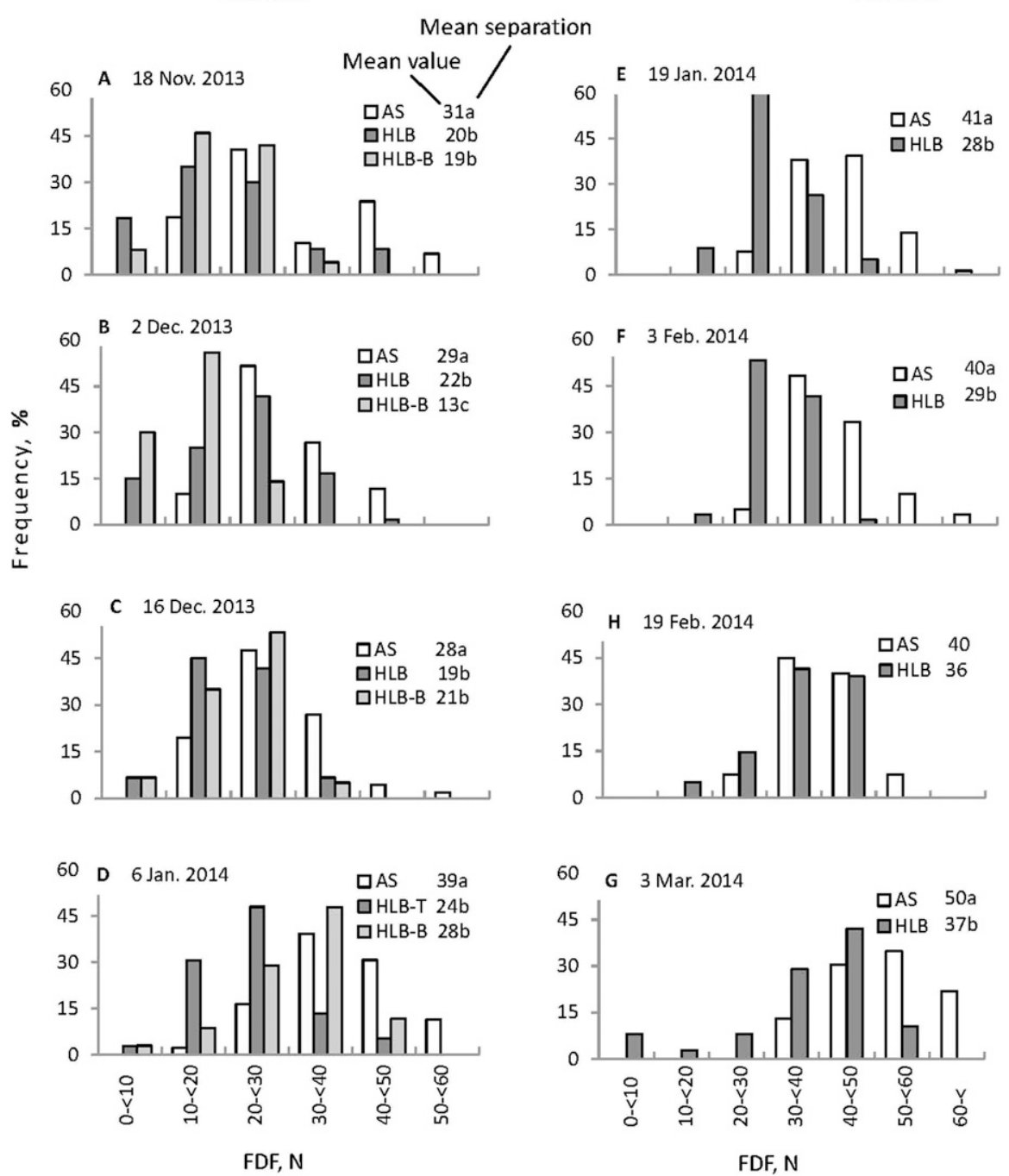

Fig. 2. Effect of HLB on distribution of fruit detachment force (FDF) presented in column graphs, and mean FDF values labeled next to the legends of fruits from four 'Hamlin' (left; A-D) and four 'Valencia' (right; $\mathbf{E}-\mathbf{H}$ ) sampling dates. The means followed by the same letter were not significantly different at $P<0.05$ level. AS $=$ fruit from HLB-asymptomatic trees; HLB = fruit from HLBsymptomatic trees, and HLB-B = fruit from HLB-symptomatic branches on largely asymptomatic trees.

the information on the relationship between HLB, AZ C formation, FDF, and preharvest fruit drop were sporadic, and there were several possible explanations, but nothing definitive.

'Valencia' fruit samples were collected from $\approx 40 \mathrm{~d}$ before commercial harvest to early commercial harvest (Fig. 2E and F). Results with 'Valencia' were similar to 'Hamlin', which were picked over the commercial harvest season (Fig. 2A-D). Results indicated that increased HLB symptom severity can accelerate abscission, thus decrease FDF, and potentially caused a high incidence of fruit drop. The increase in FDF as fruit aged was unexpected. Two possible reasons for this anomalous response include 1) loosened fruits had already dropped previous to sampling times leaving tighter (healthier) fruits on the tree or 2) thinning of fruits through abscission over the season reduced the fruit load on the tree later in the 
season, which allowed more nutrients for the remaining fruit. We compared the fruit drop trends with temperature and rainfall, but did not find any correlations (data not shown). Abscission can be triggered by a range of conditions, including excessive water loss and various forms of wounding, during which a number of molecular and physiological events occur within cells, tissues, and organs (Cheong et al., 2002). Organs separate from the mother plant due to hydrolysis of cell walls and intercellular zones beginning with perception and propagation of appropriate signals (Cheong et al., 2002; Roberts et al., 2002).

TPA profiles. Figure 3 presents the forcetime curves for AS, HLB-B, and HLB 'Hamlin' fruits using the TPA test, and each measurement resulted in four textural parameters: hardness, cohesiveness, resilience, and springiness. Hardness (peak force during the first compression cycle expressed in Newton) reflects the yield force required for fruit deformation under an external force and the magnitude of the intercellular binding force in the fruit tissue. Cohesiveness, ratio of the second compression area $\left(\mathrm{A}_{2}\right)$ and the first compression area $\left(\mathrm{A}_{1}\right)$ in a two-cycle forcetime TPA test, refers to how well the fruit withstands a second compression deformation, maintains junction and integrity during compression, and to the magnitude of the intercellular binding force. Resilience, ratio of the area of the first downstroke $\left(\mathrm{A}_{4}\right)$ to the area of the first upstroke $\left(A_{3}\right)$, refers to the capacity of the fruit to regain its original position, considering not only the distance, but also the force and speed with which the fruit bounces back after the initial deformation. Springiness, the height that the sample recovers during force relaxation time between first and second bite compression cycle, i.e., $\mathrm{L}_{2} / \mathrm{L}_{1}$, is defined as the extent to which the compressed fruit returns to its original size when the load is removed. The four parameters represent different aspects of fruit response when the fruit was pressed. Springiness could be referred to as "retarded recoverable springiness," and resilience as "instantaneous recoverable springiness" (Bourne, 1978; Mavroudis et al., 2004; Pons and Fiszman, 1996; Veland and Torrissen, 1999). Figure 3 shows a difference between AS vs. HLB and HLB-B, but no difference between HLB and HLB-B in hardness $\left(\mathrm{H}_{1}\right.$, Fig. 3).

Results of TPA parameters for HLB, HLB-B, and AS in 'Hamlin' and 'Valencia' fruits are shown in Table 2. Through the entire experiment, cohesiveness, springiness, and resilience of the AS fruits were generally higher than those of HLB and HLB-B fruits, although not always significant, regardless of sampling time or variety (Table 2). Hardness was also generally higher for AS fruit than for HLB and HLB-B, but significantly different only for the 18 Nov. 2013 harvest. Differences in cohesiveness and resilience for AS compared with HLB or HLB-B on all harvest dates for both 'Hamlin' and 'Valencia' were statistically significant (Table 2). Springiness

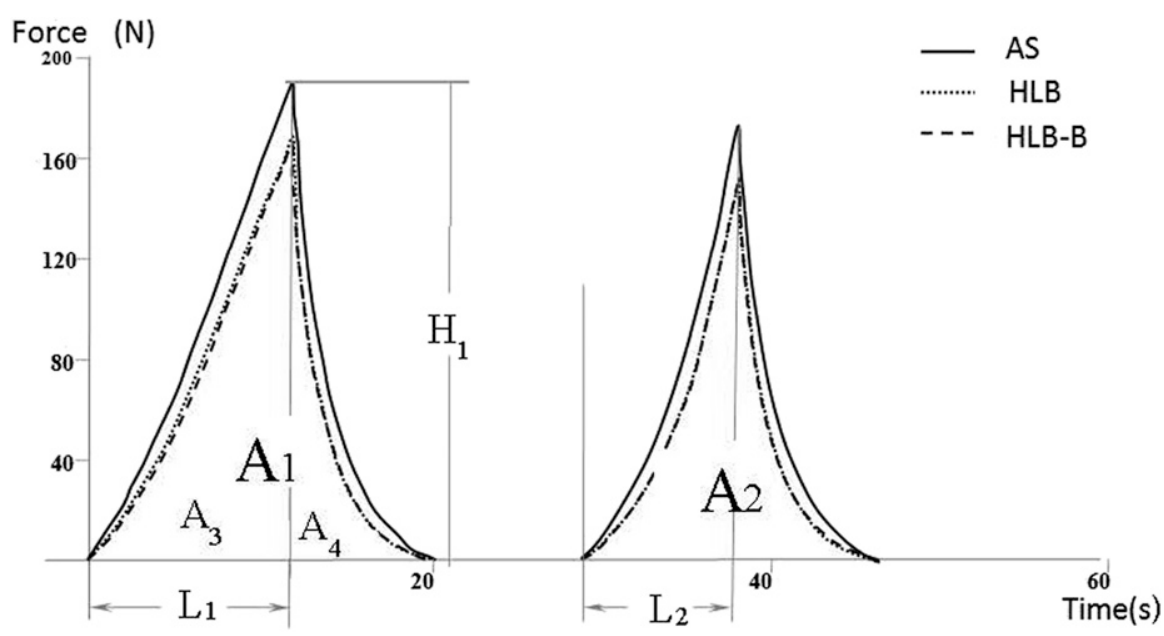

Fig. 3. Texture profile analysis test curves (a single fruit for each type/condition) for HLB-asymptomatic and -symptomatic 'Hamlin' orange samples. AS = fruit from HLB-asymptomatic trees; HLB = fruit from HLB-symptomatic trees, and HLB-B = fruit from HLB-symptomatic branches on largely asymptomatic trees; $\mathrm{H}_{1}=$ hardness (unit, $\mathrm{N}$ ); $\mathrm{A}_{2} / \mathrm{A}_{1}=$ cohesiveness; $\mathrm{A}_{4} / \mathrm{A}_{3}=$ resilience; $\mathrm{L}_{2} / \mathrm{L}_{1}=$ springiness.

Table 2. Effect of HLB on texture profile analysis parameters of fruits from four 'Hamlin' and two 'Valencia' sampling dates.

\begin{tabular}{clllll}
\hline Sampling date & HLB severity & Hardness $(\mathrm{N})$ & Cohesiveness & Springiness & Resilience \\
\hline 'Hamlin' & & & & & \\
18 Nov. 2013 & AS & $189.2 \pm 17.6 \mathrm{a}^{\mathrm{y}}$ & $0.706 \pm 0.023 \mathrm{a}$ & $0.770 \pm 0.019 \mathrm{a}$ & $0.359 \pm 0.027 \mathrm{a}$ \\
& HLB & $168.8 \pm 23.2 \mathrm{~b}$ & $0.625 \pm 0.044 \mathrm{~b}$ & $0.758 \pm 0.024 \mathrm{~b}$ & $0.324 \pm 0.034 \mathrm{~b}$ \\
& HLB-B & $167.8 \pm 34.5 \mathrm{~b}$ & $0.634 \pm 0.033 \mathrm{~b}$ & $0.760 \pm 0.026 \mathrm{~b}$ & $0.329 \pm 0.030 \mathrm{~b}$ \\
2 Dec. 2013 & AS & $168.5 \pm 16.8 \mathrm{a}$ & $0.652 \pm 0.019 \mathrm{a}$ & $0.775 \pm 0.013 \mathrm{a}$ & $0.353 \pm 0.019 \mathrm{a}$ \\
& HLB & $161.0 \pm 21.0 \mathrm{a}$ & $0.636 \pm 0.039 \mathrm{~b}$ & $0.764 \pm 0.200 \mathrm{ab}$ & $0.343 \pm 0.027 \mathrm{~b}$ \\
& HLB-B & $161.1 \pm 25.2 \mathrm{a}$ & $0.634 \pm 0.034 \mathrm{~b}$ & $0.758 \pm 0.022 \mathrm{~b}$ & $0.338 \pm 0.026 \mathrm{~b}$ \\
16 Dec. 2013 & AS & $155.4 \pm 16.7 \mathrm{a}$ & $0.637 \pm 0.023 \mathrm{a}$ & $0.766 \pm 0.019 \mathrm{a}$ & $0.336 \pm 0.024 \mathrm{a}$ \\
& HLB & $153.9 \pm 25.0 \mathrm{a}$ & $0.624 \pm 0.034 \mathrm{~b}$ & $0.759 \pm 0.024 \mathrm{ab}$ & $0.328 \pm 0.047 \mathrm{ab}$ \\
& HLB-B & $151.8 \pm 25.8 \mathrm{a}$ & $0.612 \pm 0.026 \mathrm{~b}$ & $0.755 \pm 0.025 \mathrm{~b}$ & $0.318 \pm 0.028 \mathrm{~b}$ \\
6 Jan. 2014 & AS & $149.5 \pm 16.0 \mathrm{a}$ & $0.632 \pm 0.023 \mathrm{a}$ & $0.759 \pm 0.017 \mathrm{a}$ & $0.335 \pm 0.021 \mathrm{a}$ \\
& HLB & $151.7 \pm 23.1 \mathrm{a}$ & $0.616 \pm 0.028 \mathrm{~b}$ & $0.756 \pm 0.022 \mathrm{ab}$ & $0.324 \pm 0.024 \mathrm{~b}$ \\
& HLB-B & $144.6 \pm 24.2 \mathrm{a}$ & $0.612 \pm 0.027 \mathrm{~b}$ & $0.748 \pm 0.025 \mathrm{~b}$ & $0.317 \pm 0.025 \mathrm{~b}$ \\
'Valencia' & & & & & \\
19 Jan. 2014 & AS & $190.6 \pm 18.4 \mathrm{a}$ & $0.719 \pm 0.023 \mathrm{a}$ & $0.814 \pm 0.012 \mathrm{a}$ & $0.397 \pm 0.018 \mathrm{a}$ \\
& HLB & $177.3 \pm 26.3 \mathrm{a}$ & $0.673 \pm 0.032 \mathrm{~b}$ & $0.808 \pm 0.020 \mathrm{a}$ & $0.374 \pm 0.026 \mathrm{~b}$ \\
3 Mar. 2014 & AS & $227.3 \pm 35.9 \mathrm{a}$ & $0.627 \pm 0.039 \mathrm{a}$ & $0.759 \pm 0.017 \mathrm{a}$ & $0.322 \pm 0.028 \mathrm{a}$ \\
& HLB & $206.7 \pm 40.4 \mathrm{a}$ & $0.505 \pm 0.126 \mathrm{~b}$ & $0.703 \pm 0.052 \mathrm{~b}$ & $0.253 \pm 0.062 \mathrm{~b}$ \\
\hline
\end{tabular}

${ }^{\mathrm{z}} \mathrm{AS}=$ fruit from HLB-asymptomatic trees; HLB $=$ fruit from HLB-severely symptomatic trees, and HLB$\mathrm{B}=$ fruit from HLB-symptomatic branches in trees with $>50 \%$ asymptomatic canopy.

${ }^{y}$ Mean \pm SD. Values within a column in same day followed by the same letter were not significantly different at $P \leq 0.05$.

on 18 Nov. 2013 for 'Hamlin' and on 3 Mar. 2014 for 'Valencia' was significantly lower in both types of HLB-symptomatic fruits compared with AS. TPA hardness decreased in 'Hamlin', but increased in 'Valencia' with maturity (Table 2).

Our data indicate that HLB-symptomatic fruits had reduced elastic responses in sweet oranges. The orange fruit is composed of peel, support tissues, and soft pulp tissues. The mechanical properties of the support tissues and the peel depend primarily on cellulose and pectic substances, whereas mechanical properties of the soft tissues are governed mainly by the turgor pressure generated by the water in the cells and vacuoles. Distinctions between cell zones are gradual, and the turgor pressure decreases during maturity, which leads to fruit softening, and may be associated with flavor formation (Huber, 1983; McCann et al.,
1990; Seymour and Gross, 1996; Seymour et al., 2013).

Puncture profiles. Puncture tests measure puncture resistance of fruits. Force-time curves of the three types of 'Hamlin' fruits are shown in Fig. 4. The force-time curve can result in three puncture parameters including puncture force, deformation, and toughness, to represent the different aspects of fruits when pressed by a twig, branch, or other thin and sharp subjects. Force continuously increased linearly until the rupture point at which the orange peel was broken (or punctured), this measurement is called puncture force, expressed in Newton (Fig. 4). Then, the force suddenly falls to a lower level as the probe moves through the peel and into the pulp tissue, whose resistance force varied slightly because of the heterogeneity of the pulp texture (Flood et al., 2006). Deformation was the puncture depth $(\mathrm{mm})$ of the probe 
from first contact at the orange peel surface to the depth of the peel rupture point, representing the maximum deformation level of the structure. Toughness indicated the deformation capacity of the peel to resist rupture and the energy necessary to break the peel, which was equal to the area under the force-time curve (Camps et al., 2005; Huu-Thuan et al., 2010; Sirisomboon et al., 2012). Figure 4 shows the differences in puncture force between AS, HLB, and HLB-B fruits.

As shown in Table 3, for 'Hamlin' and 'Valencia' at each time of sampling, puncture force, deformation, and toughness of

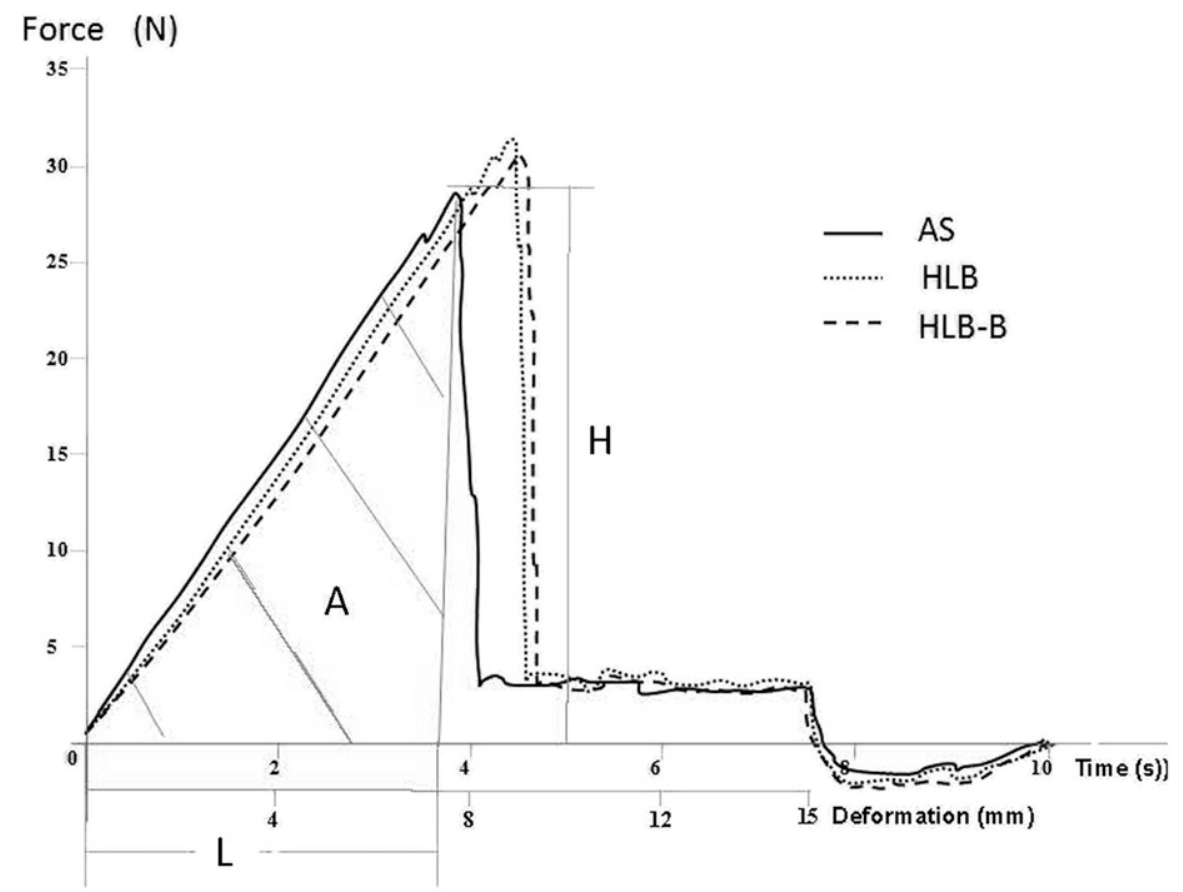

Fig. 4. Puncture test curves (a single fruit for each type/condition) for HLB-asymptomatic and HLBsymptomatic 'Hamlin' orange samples. AS = fruit from HLB-asymptomatic trees; HLB = fruit from HLB-symptomatic trees, and HLB-B = fruit from HLB-symptomatic branches on largely asymptomatic trees; $\mathrm{H}=$ puncture force (unit, $\mathrm{N}$ ); $\mathrm{L}=$ deformation (unit, $\mathrm{mm}$ ); $\mathrm{A}$ = toughness (unit, Ns, Newton second).

Table 3. Effect of HLB on puncture test parameters of fruits from four 'Hamlin' and two 'Valencia' sampling dates.

\begin{tabular}{clccc}
\hline Sampling date & HLB severity & Puncture force (N) & Deformation (mm) & Toughness (Ns) \\
\hline 'Hamlin' & & & & \\
18 Nov. 2013 & AS & $23.1 \pm 2.3 \mathrm{~b}^{\mathrm{z}}$ & $6.0 \pm 0.5 \mathrm{~b}$ & $53.8 \pm 6.0 \mathrm{~b}$ \\
& HLB & $25.1 \pm 4.0 \mathrm{a}$ & $7.4 \pm 2.1 \mathrm{a}$ & $62.7 \pm 14.1 \mathrm{a}$ \\
& HLB-B & $26.6 \pm 5.0 \mathrm{a}$ & $7.2 \pm 1.8 \mathrm{a}$ & $63.7 \pm 16.4 \mathrm{a}$ \\
2 Dec. 2013 & AS & $21.1 \pm 2.1 \mathrm{~b}$ & $6.1 \pm 0.8 \mathrm{~b}$ & $49.5 \pm 5.4 \mathrm{~b}$ \\
& HLB & $23.3 \pm 4.2 \mathrm{a}$ & $6.6 \pm 1.2 \mathrm{ab}$ & $54.8 \pm 9.1 \mathrm{ab}$ \\
& HLB-B & $24.3 \pm 3.8 \mathrm{a}$ & $7.2 \pm 1.4 \mathrm{a}$ & $58.5 \pm 12.3 \mathrm{a}$ \\
16 Dec. 2013 & AS & $17.8 \pm 2.0 \mathrm{~b}$ & $5.3 \pm 0.7 \mathrm{~b}$ & $42.3 \pm 5.0 \mathrm{~b}$ \\
& HLB & $20.3 \pm 3.7 \mathrm{a}$ & $6.3 \pm 1.2 \mathrm{a}$ & $47.8 \pm 10.7 \mathrm{a}$ \\
6 Jan. 2014 & HLB-B & $20.6 \pm 3.5 \mathrm{a}$ & $6.3 \pm 1.3 \mathrm{a}$ & $47.9 \pm 10.8 \mathrm{a}$ \\
& AS & $17.1 \pm 2.7 \mathrm{~b}$ & $5.2 \pm 0.9 \mathrm{~b}$ & $40.5 \pm 6.7 \mathrm{~b}$ \\
& HLB & $19.5 \pm 3.4 \mathrm{a}$ & $5.8 \pm 1.0 \mathrm{a}$ & $45.8 \pm 10.0 \mathrm{a}$ \\
'Valencia' & HLB-B & $20.6 \pm 3.6 \mathrm{a}$ & $6.3 \pm 1.1 \mathrm{a}$ & $47.2 \pm 10.8 \mathrm{a}$ \\
19 Jan. 2014 & AS & $21.3 \pm 2.5 \mathrm{~b}$ & $5.6 \pm 0.7 \mathrm{~b}$ & $56.6 \pm 7.9 \mathrm{~b}$ \\
& HLB & $24.4 \pm 3.8 \mathrm{a}$ & $6.0 \pm 1.0 \mathrm{a}$ & $61.1 \pm 10.4 \mathrm{a}$ \\
3 Mar. 2014 & AS & $21.9 \pm 3.8 \mathrm{~b}$ & $6.7 \pm 0.8 \mathrm{~b}$ & $11.7 \pm 26.8 \mathrm{~b}$ \\
& HLB & $28.2 \pm 8.2 \mathrm{a}$ & $8.4 \pm 2.6 \mathrm{a}$ & $152.9 \pm 58.3 \mathrm{a}$ \\
\hline
\end{tabular}

${ }^{\mathrm{z}} \mathrm{AS}$ = fruit from HLB-asymptomatic trees; HLB = fruit from HLB-symptomatic trees; and HLB-B = fruit from HLB-symptomatic branches in trees with $>50 \%$ asymptomatic canopy.

${ }^{\mathrm{y}}$ Mean \pm SD. Values within a column in same day followed by the same letter were not significantly different at $P \leq 0.05$.
Differences in the mechanical properties between fruits resulted mainly from the structure of fruit, which is dependent on both peel weakness and whole pulp firmness (Sirisomboon et al., 2012). The intercellular binding force decreased with degradation of the cell wall substances, such as pectin, cellulose, hemicellulose etc., maintaining the fruit hardness (McCann et al., 1990; Seymour and Gross, 1996). Accordingly, TPA hardness of 'Hamlin' fruits exhibited an overall decreasing trend with time of harvest for all fruit types (HLB, HLB-B, and AS) (Table 2). Similar trends were also reported by Juste et al. (1988) and McDonald and Shaw (1987). They indicated that maturity has a profound effect on fruit firmness. Puncture force in 'Hamlin' decreased remarkably over the harvest season, regardless of HLB severity, indicating that the laterharvested fruits were more sensitive to puncture damage. In addition, the data show that symptomatic HLB fruits are more resistant to puncture compared with AS fruits.

In conclusion, FDF was found to be similar for HLB and HLB-B fruit, but higher for AS fruit. This may contribute to the high incidence of preharvest fruit drop for symptomatic HLB trees. In general, HLBsymptomatic fruits were softer and had a lower capacity for recovery once compressed compared with AS fruits. On the other hand, the peel of HLB-symptomatic fruits was more resistant to puncture damage than for AS fruits. HLB affected trees have been reported to have impaired root systems (Graham et al., 2013) that perhaps could result in less fruit turgor pressure, which might impact fruit firmness.

\section{Literature Cited}

Ahmed, E.M., F.G. Martin, and R.C. Fluck. 1973. Damaging stresses to fresh and irradiated citrus fruits. J. Food Sci. 38:230-233.

Baldwin, E., J. Bai, A. Plotto, J. Manthey, J. Narciso, S. Dea, and M. Irey. 2012. Effect of nutritional spray regimes on orange juice flavor quality and juice Liberibacter (CLas) DNA detection. Proc. Fla. State Hort. Soc. 125: 239-242.

Baldwin, E., A. Plotto, J. Manthey, G. McCollum, J. Bai, M. Irey, R. Cameron, and G. Luzio. 2010. Effect of liberibacter infection (Huanglongbing disease) of citrus on orange fruit physiology and fruit/fruit juice quality: Chemical and physical analyses. J. Agr. Food Chem. 58:1247-1262.

Bassanezi, R.B., L.H. Montesino, M.C.G. Gasparoto, F.A. Bergamin, and L. Amorim. 2011. Yield loss caused by huanglongbing in different sweet orange cultivars in São Paulo, Brazil. Eur. J. Plant Pathol. 130:577-586.

Bourne, M.C. 1978. Texture profile analysis. Food Technol. 32:62-66, 72.

Bové, J.M. 2006. Huanglongbing: A destructive, newly-emerging, century-old disease of citrus. J. Plant Pathol. 88:7-37.

Burns, J.K., L.V. Pozo, C.R. Arias, and B. Hockema. 2003. Coronatine and abscission in citrus. J. Amer. Soc. Hort. Sci. 128:309-315.

Camps, C., P. Guilermin, J.C. Mauget, and D. Bertrand. 2005. Data analysis of penetrometric force/displacement curves for the 
characterization of whole apple fruits. J. Texture Stud. 36:387-401.

Cheong, Y.H., H.S. Chang, R. Gupta, Z.T. Wang, and S. Luan. 2002. Transcriptional profiling reveals novel interactions between wounding, pathogen, abiotic stress, and hormonal responses in Arabidopsis. Plant Physiol. 129: 661-677.

Churchill, D.B., H.R. Sumner, and J.D. Whitney. 1980. Peel strength properties of three orange varieties. Trans. ASAE 23:173-176.

da Graça, J.V. 1991. Citrus greening disease. Ann. Rev. Phytopathol. 29:109-136.

Etxeberria, E.D., P. Gonzalez, D. Achor, and G. Albrigo. 2009. Anatomical distribution of abnormally high levels of starch in HLB-affected Valencia orange trees. Physiol. Mol. Plant Pathol. 74:76-83.

Flood, S.J., T.F. Burks, and A.A. Teixeira. 2006. Physical properties of oranges in response to applied gripping forces for robotic harvesting. Trans. ASABE 49:341-346.

Gottwald, T.R. 2010. Current epidemiological understanding of citrus huanglongbing. Annu. Rev. Phytopathol. 48:119-139.

Graham, J.H., E.G. Johnson, T.R. Gottwald, and M.S. Irey. 2013. Presymptomatic fibrous root decline in citrus trees caused by huanglongbing and potential interaction with Phytophthora spp. Plant Dis. 97:1195-1199.

Grotte, M., F. Duprat, D. Loonis, and E. Piétri. 2001. Mechanical properties of the skin and the flesh of apples. Intl. J. Food Prop. 4:149-161.

Huber, D.J. 1983. The role of cell wall hydrolases in fruit softening. Hort. Rev. 5:169-219.

Huu-Thuan, B., J.Y. Makhlouf, and C. Ratti. 2010. Postharvest ripening characterization of greenhouse tomatoes. Intl. J. Food Prop. 13:830-846.

Juste, F., C. Gracia, E. Molto, R. Eranez, and S. Castillo. 1988. Fruit bearing zones and physical properties of citrus for mechanical harvesting. Proc. Sixth Int. Citrus Cong., Israel, 4:18011809.

Kostenyuk, I.A. and J.K. Burns. 2004. Mechanical wounding and abscission in citrus. Physiol. Plant. 122:354-361.
Li, W., J.S. Hartung, and L. Levy. 2006. Quantitative real-time PCR for detection and identification of Candidatus Liberibacter species associated with citrus huanglongbing. J. Microbiol. Methods 66:104-115.

Liao, H.L. and J.K. Burns. 2012. Gene expression in Citrus sinensis fruit tissues harvested from huanglongbing-infected trees: Comparison with girdled fruit. J. Expt. Bot. 63:3307-3319.

Mavroudis, N.E., P. Dejmek, and I. Sjoholm. 2004. Studies on some raw material characteristics in different Swedish apple varieties. J. Food Eng. 62:121-129.

McCann, M.C., B. Wells, and K. Roberts. 1990. Direct visualization of cross-links in the primary plant cell wall. J. Cell Sci. 96:323-334.

McDonald, R.E. and P.E. Shaw. 1987. Effect of gibberellic acid on certain physical and chemical properties of grapefruit. Trop. Sci. 27:1721.

Miller, W.M. 1986. Mechanical and physical properties for postharvest handling of Florida citrus. Proc. Fla. State Hort. Soc. 99:122-127.

Ortiz, C. and A. Torregrosa. 2014. Mechanical properties of citrus and impact damage under different storage conditions. Trans. ASABE 57:593-598.

Plotto, A., E. Baldwin, G. McCollom, J. Manthey, J. Narciso, and M. Irey. 2010. Effect of Liberibacter infection (huanglongbing or "greening" disease) of citrus on orange juice flavor quality by sensory evaluation. J. Food Sci. 75:220-230.

Pons, M. and S.M. Fiszman. 1996. Instrumental texture profile analysis with particular reference to gelled systems. J. Texture Stud. 27: 597-624.

Pozo, L., R. Yuan, I. Kostenyuk, F. Alférez, G.Y. Zhong, and J.K. Burns. 2004. Differential effects of 1-methylcyclopropene on citrus leaf and mature fruit abscission. J. Amer. Soc. Hort. Sci. 129:473-478.

Racskó, J., M. Soltész, Z. Szabó, and J. Nyéki. 2006. Fruit drop: II. Biological background of flower and fruit drop. Intl. J. Hort. Sci. 12:103-108.
Rahman, M.S., Q. Al-Shamsi, A. Abdullah, M.R. Claereboudt, B. Al-Belushi, R. Al-Maqbali, and J. Al-Sabahi. 2012. Classification of commercial Omani halwa by physico-chemical properties and instrumental texture profile analysis. Ital. J. Food Sci. 24:292-304.

Roberts, J.A., K.A. Elliot, and Z.H. GonzalezCarranza. 2002. Abscission, dehiscence, and other cell separation processes. Annu. Rev. Plant Biol. 53:131-158.

Rosales, R. and J.K. Burns. 2011. Phytohormone changes and carbohydrate status in sweet orange fruit from Huanglongbing-infected trees. J. Plant Growth Regul. 30:312-321.

Seymour, G.B. and K.C. Gross. 1996. Cell wall disassembly and fruit softening. Postharvest News Inform. 7:45-52.

Seymour, G.B., L. Ostergaard, N.H. Chapman, S. Knapp, and C. Martin. 2013. Fruit development and ripening. Annu. Rev. Plant Biol. 64:219-241.

Singh, K.K. and B.S. Reddy. 2006. Postharvest physico-mechanical properties of orange peel and fruit. J. Food Eng. 73:112-120.

Sirisomboon, P., M. Tanaka, and T. Kojima. 2012. Evaluation of tomato textural mechanical properties. J. Food Eng. 111:618-624.

USDA NASS. 2015. Citrus fruits 2015 summary. National Agricultural Statistics Service, Washington, DC. 11 Feb. 2016. <http://usda.mannlib. cornell.edu/usda/current/CitrFrui/CitrFrui-09-172015.pdf $>$.

Veland, J.O. and J.O. Torrissen. 1999. The texture of Atlantic salmon (Salmo salar) muscle as measured instrumentally using TPA and Warner-Brazler shear test. J. Sci. Food Agr. 79:1737-1746.

Zhao, W., J. Bai, T.G. McCollum, and E.A. Baldwin. 2015. High incidence of preharvest colonization of huanglongbing-symptomatic Citrus sinensis fruit by Lasiodiplodia theobromae (Diplodia natalensis) and exacerbation of postharvest fruit decay by that fungus. Appl. Environ. Microbiol. 81: 364-372. 